\title{
Susceptibility profile and metabolic mechanisms involved in Aedes aegypti and Aedes albopictus resistant to DDT and deltamethrin in the Central African Republic
}

Carine Ngoagouni ${ }^{1 *}$ D, Basile Kamgang ${ }^{2}$, Cécile Brengues ${ }^{3}$, Gildas Yahouedo $^{3}$, Christophe Paupy $^{3}$, Emmanuel Nakouné ${ }^{1}$, Mirdad Kazanji1 ${ }^{1,4}$ and Fabrice Chandre ${ }^{3}$

\begin{abstract}
Background: Aedes aegypti and Ae. albopictus are the main epidemic vectors of dengue, chikungunya and Zika viruses worldwide. Their control during epidemics relies mainly on control of larvae and adults with insecticides. Unfortunately, loss of susceptibility of both species to several insecticide classes limits the efficacy of interventions. In Africa, where Aedes-borne viruses are of growing concern, few data are available on resistance to insecticides. To fill this gap, we assessed the susceptibility to insecticides of Ae. aegypti and Ae. albopictus populations in the Central African Republic (CAR) and studied the mechanisms of resistance.

Methods: Immature stages were sampled between June and September 2014 in six locations in Bangui (the capital of (AR) for larval and adult bioassays according to WHO standard procedures. We also characterized DDT- and pyrethroid-resistant mosquitoes molecularly and biochemically, including tests for the activities of nonspecific esterases ( $\alpha$ and $\beta$ ), mixed-function oxidases, insensitive acetylcholinesterase and glutathione $S$-transferases.

Results: Larval bioassays, carried out to determine the lethal concentrations ( $\mathrm{LC}_{50}$ and $\left.L C_{95}\right)$ and resistance ratios $\left(R_{50}\right.$ and $\left.R R_{95}\right)$, suggested that both vector species were susceptible to Bacillus thuringiensis var. israeliensis and to temephos. Bioassays of adults showed susceptibility to propoxur and fenitrothion, except for one Ae. albopictus population that was suspected to be resistant to fenithrothion. None of the Ae. aegypti populations was fully susceptible to DDT. Ae. albopictus presented a similar profile to Ae. aegypti but with a lower mortality rate (41\%). Possible resistance to deltamethrin was observed among Ae. aegypti and Ae. albopictus, although some were susceptible. No kdr mutations were detected in either species; however, the activity of detoxifying enzymes was higher in most populations than in the susceptible Ae. aegypti strain, confirming decreased susceptibility to DDT and deltamethrin.
\end{abstract}

Conclusion: These findings suggested that regular, continuous monitoring of resistance is necessary in order to select the most effective adulticides for arbovirus control in Bangui.

Keywords: Aedes aegypti, Aedes albopictus, Arboviruses, Vectors, Insecticide resistance, Metabolic resistance, Central African Republic

* Correspondence: ngoagounic@yahoo.fr

${ }^{1}$ Institut Pasteur de Bangui, PO Box 923, Bangui, Central African Republic

Full list of author information is available at the end of the article 


\section{Background}

Aedes aegypti and Ae. albopictus are the main vectors of dengue virus (DENV, Flaviviridae, Flavivirus), chikungunya virus (CHIKV, Togaviridae, Alphavirus) and Zika virus (ZIKV, Flaviviridae, Flavivirus) worldwide. Aedes aegypti is native to Africa and is found throughout the tropics, whereas Ae. albopictus is native to Asia but has recently spread to all continents. These three viruses are increasing global health threats, spreading from their original niches to most areas of the world. Dengue virus infection is a serious health problem for 2.5 billion people worldwide. A recent estimate indicated 390 million infections per year (95\% credible interval, 284-528 million), of which 96 million (67-136 million) manifest clinically, although the actual number of cases is under-reported, and many cases are not definitively classified [1]. Dengue infection causes more illness and deaths in humans than any other arboviral disease, the severity ranging from mild dengue fever to dengue haemorrhagic fever and dengue shock syndrome. Chikungunya fever is also as a significant worldwide public health problem; particular attention has been paid to this disease after its rapid, massive emergence in the south-west Indian Ocean, India and the Americas [2]. Chikungunya can manifest as asymptomatic to severe infections, mainly with severe arthralgia but also with cardiovascular, neurological and respiratory symptoms $[3,4]$. ZIKV, which was originally isolated in 1947 from a monkey in Uganda [5], has occasionally been reported in humans in Africa and Asia [6], but, after its sudden emergence in 2007 on Yap Island, affecting about 5,000 people [7], it caused successive outbreaks in French Polynesia in 2013-2014 [8] and in Brazil since October 2015, before spreading across Latin America [9]. The recrudescence of ZIKV has been associated with reports of neurological disorders and microcephaly, and the World Health Organization (WHO) declared it a "public health emergency of international concern" on 1 February 2016 [10].

In Central Africa, several arboviruses, including DENV, CHIKV and ZIKV have been isolated from mosquitoes and human samples, but no massive outbreak was reported before introduction of the new competent vector Ae. albopictus. After it was first reported in 2000 in Cameroon [11], it spread rapidly to numerous countries in Central Africa and, with the native species Ae. aegypti, played a role in disseminating and spreading DENV, CHIKV and ZIKV in urban and rural environments $[6,12-14]$. This change in the epidemiology of these three arboviruses is particularly disturbing because the region has many potentially suitable niches for Ae. albopictus, and several arboviruses of medical and veterinary concern are endemic [15]. In view of the current lack of effective vaccines or specific drugs against these arboviral infections, vector control remains the most effective means for their prevention [16].
Insecticides play a major role in the control of mosquito vectors, and synthetic pyrethroids are the chemicals of choice because of their effective, rapid activity against insects, their low toxicity for mammals and their degradability in the environment $[17,18]$. WHO recommends use of pyrethroids against adult mosquitoes and larvicides such as Bacillus thuringiensis var. israeliensis (Bti), organophosphates like temephos, benzoylureas like diflubenzuron, juvenile hormone mimics like pyriproxyfen and spinosyns such as spinosad for larval control [19]. Unfortunately, long-term intensive use of insecticides usually leads to the emergence of resistance in mosquito species under selection pressure, and this is one of the major obstacles to the control of arthropod pests [20, 21]. Many control programmes are threatened by insecticide resistance in Ae. aegypti and Ae. albopictus. Aedes aegypti has been reported to be resistant to pyrethroids and organophosphates in various part of the world, whereas few data are available on insecticide resistance in Ae. albopictus. The few studies that have been conducted show decreased susceptibility of Ae. albopictus to a wide variety of active ingredients, including organophosphates, organochlorines (DDT) and pyrethroids.

Insecticide resistance in insects is due to two main mechanisms: enhanced metabolic detoxification and insensitivity of target sites [22]. The first mechanism involves overexpression or qualitative changes in the catalytic sites of enzymes such as non-specific esterases (NES), glutathione $S$-transferases (GST) and mixed-function oxidases (MFO). Previous studies outside Africa on metabolic resistance mechanism in Ae. aegypti and Ae. albopictus showed that most of detoxification enzymes linked to insecticide resistance belong to the cytochrome $\mathrm{P} 450$ genes $[23,24]$. Target insensitivity is due to mutations that reduce the binding affinity between the insecticide and its physiological target. Pyrethroids and DDT acts on voltage-sensitive sodium channels, and insects develop resistance to these types of insecticide through substitution(s) of one or several amino acids in the channel sequence [25]. These mutations in the voltage-sensitive sodium channel are known as "knockdown resistance" $(k d r)$ and have been reported in several mosquito genera, including Anopheles gambiae [26], An. stephensi [27], Culex pipiens [28] and Ae. aegypti [29]. In many mosquito species, including $A e$. aegypti, $k d r$ related to pyrethroids and DDT has been located in segment 6 of domain II [23, 29-31], with other mutations at the same position (I1011M, I1011 V, V1016G and V1016I) [32]. In South-East Asia, for example, two major voltage-gated sodium channel haplotypes (S989P + V1016G and F1534C) confer resistance of Ae. aegypti to pyrethroids, and species with these two haplotypes are widely and sympatrically distributed in that region [33-35]. Neurophysiological studies have revealed that V1016G and F1534C single mutations each confer 
resistance to pyrethroids [36]. Such $k d r$ mutations are rare in Ae. albopictus; the mutation F1534C (TTC to TGC) at segment 6 of domain III described in Ae. aegypti is the only one that has been confirmed in $A e$. albopictus from Singapore [37].

In Africa, most of the data on insecticide susceptibility concerns malaria vectors (Anopheles mosquitoes), and very little is known about Aedes. Most of the studies on Ae. aegypti in West and Central Africa date back 30-40 years [38], although resistance of Ae. aegypti and Ae. albopictus was reported in Cameroon after introduction of Ae. albopictus [39]. In CAR, both species are present, but Ae. albopictus predominates over Ae. aegypti at all sites in Bangui and southern CAR, where the two species are sympatric [40]. The lack of data on their susceptibility to insecticides used in public health is a growing obstacle for dengue, chikungunya and Zika disease control programmes. We assessed the susceptibility of larvae and adults of Ae. aegypti and Ae. albopictus to insecticides and the mechanism involved in order to select the best insecticides for use in an outbreak and to manage resistance in these populations.

\section{Methods}

\section{Mosquito strains and collection}

Field-caught larval or pupal Ae. aegypti and Ae. albopictus $\left(\mathrm{F}_{0}\right.$ generation) were sampled between June and
September 2014, during the rainy season, in six districts of Bangui (Fig. 1). All samples were taken to the insectaries at the Institut Pasteur de Bangui (IPB) and maintained under controlled conditions $\left(28 \pm 2{ }^{\circ} \mathrm{C}\right.$ and $80 \pm$ $10 \%$ relative humidity); larvae were fed dry cat food. After emergence, adult Aedes mosquitoes were identified morphologically [41], grouped by species and site into cages and fed $10 \%$ sugar solution. Some of the $\mathrm{F}_{0}$ adults were used in adult bioassays, molecular and biochemical studies, and the remainder were used to obtain the next generation $\left(\mathrm{F}_{1}\right)$. Females were allowed to feed on blood from rabbits to induce egg-laying. $F_{1}$ eggs were hatched to obtain larvae for use in larval bioassays. The insecticides tested were chosen from the four main classes of adulticides (organochlorines, pyrethroids, carbamates and organophosphates) and two of larvicides (Bti and temephos). The reference strain (Ae. aegypti SBE) originating from Benin and papers impregnated with adulticides and $B t i$ were supplied by the MiVEGEC project (Maladies Infectieuses et Vecteurs: Écologie, Génétique, Évolution, contrôle) (Université de Montpellier, France).

\section{Larval bioassays}

Larval bioassays were performed according to standard WHO guidelines [42] using F1 larvae. The susceptibility of larvae was evaluated against technical-grade temephos (97.3\%; Sigma Aldrich-Pestanal ${ }^{\circ}$, Seelze, Germany) and a

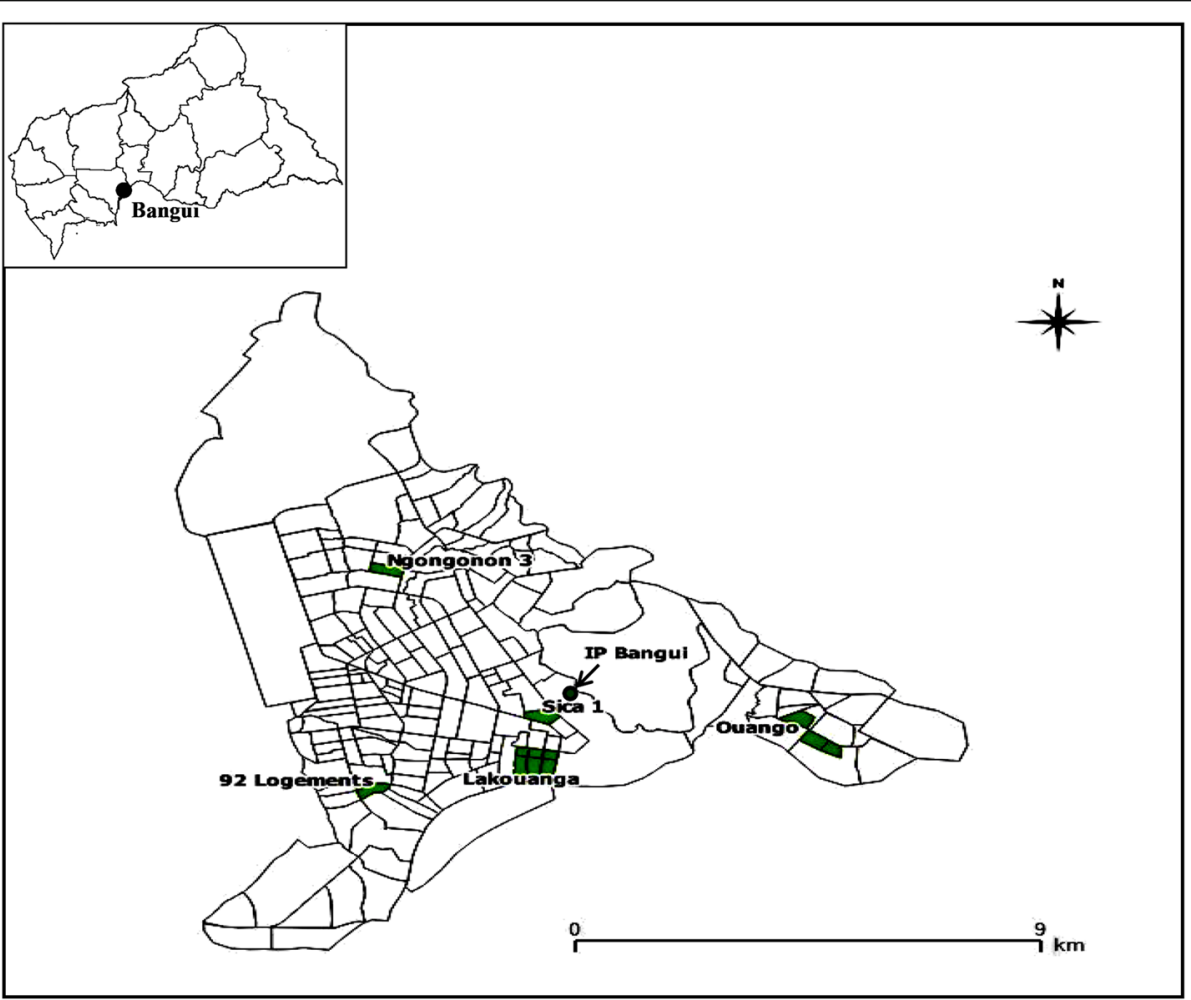

Fig. 1 Map of Bangui showing sampling sites 
formulated Bti product (Vectobac ${ }^{\circ}$ 12AS, $1200 \mathrm{ITU} / \mathrm{mg}$ ). First, stock solutions and serial dilutions were prepared in $95 \%$ ethanol (temephos) or distilled water (Bti) and stored at $4{ }^{\circ} \mathrm{C}$. For $B t i$, five concentrations ranging from 0.08 to $0.2 \mathrm{mg} / \mathrm{l}$ and for temephos, eight doses ranging from 0.0025 to $0.009 \mathrm{mg} / \mathrm{l}$ have been used in larval bioassay. Fifty to 100 larvae per concentration (with three to four replicates, depending on the sample and the number of larvae available) were tested. Third late or early fourth-instar larvae of each species were placed in plastic cups containing $99 \mathrm{ml}$ of tap water, and $1 \mathrm{ml}$ of insecticide solution at the required concentration was added. Control groups were run systematically with larvae exposed to $1 \mathrm{ml}$ of ethanol (for temephos) or $1 \mathrm{ml}$ of tap water (for Bti). No food was provided to larvae during the bioassays, which were run at $28 \pm 2{ }^{\circ} \mathrm{C}$ and $80 \pm$ $10 \%$ relative humidity. Mortality was determined after $24 \mathrm{~h}$ of exposure to the insecticide. Mortality rates were corrected with Abbott's formula [43] when the mortality of controls was $>5 \%$.

All data were analysed with Win DL v. 2.0 software [44]. Lethal concentrations ( $\mathrm{LC}_{50}$ and $\mathrm{LC}_{95}$ ) were calculated with their 95\% confidence intervals (CIs). Resistance ratios $\left(R R_{50}\right.$ and $\left.R R_{95}\right)$ were calculated by comparing the $\mathrm{LC}_{50}$ and $\mathrm{LC}_{95}$ for each species with those of susceptible strain, as $\mathrm{RR}_{50(95)}=\mathrm{LC}_{50(95)}$ of studied population $/ \mathrm{LC}_{50(95)}$ susceptible strain and $\mathrm{RR}_{95}=$ $\mathrm{LC}_{95(95)}$ of studied population/LC $\mathrm{L}_{95(95)}$ reference strain. Mosquito populations were considered as resistant when $\mathrm{RR}$ was higher than 1 and confidence intervals for $\mathrm{LC}_{50}$ or $\mathrm{LC}_{95}$ did not overlap those of the susceptible reference strain.

\section{Adult bioassays}

Adult bioassays were performed with non-blood-fed females according to the standard WHO guidelines [42]. Four insecticides 4\% DDT (organochlorine), $0.05 \%$ deltamethrin (pyrethroid), $0.1 \%$ propoxur (carbamate) and $0.5 \%$ fenitrothion (organophosphate) were tested. Two to four batches of 25 non-blood-fed females (2-4 days of age) were introduced into WHO tubes containing impregnated filter papers and exposed for $60 \mathrm{~min}$. For every test, a control assay was run in parallel with untreated papers. The number of knockdown $(\mathrm{Kd})$ mosquitoes was counted every $5 \mathrm{~min}$ during the $60 \mathrm{~min}$. After exposure, females were transferred for $24 \mathrm{~h}$ into holding tubes (and allowed to feed on a 10\% sugar solution) before being checked for mortality. Assays were carried out at $28 \pm 2{ }^{\circ} \mathrm{C}$ and a relative humidity of $80 \pm 10 \%$. The susceptibility of the mosquitoes was classified according to the WHO criteria [45] as susceptible when mortality was $>97 \%$, resistant when mortality was $<90 \%$ and possibly resistant when mortality was $90-97 \%$. Surviving females were killed and stored individually at $-80{ }^{\circ} \mathrm{C}$ in
Eppendorf tubes (according to insecticide); dead mosquitoes were stored in silica gel. As in the larval bioassays, Win DL software version 2.0 was used to estimate the $\mathrm{KdT}_{50}$ and $\mathrm{KdT}_{95}$ and their $95 \%$ CIs.

\section{Screening of $k d r$ mutation in Aedes aegypti and Aedes albopictus}

DDT- and deltamethrin-resistant specimens of Ae. aegypti and Ae. albopictus were examined for the presence of $k d r$ mutations. The total DNA of each surviving specimen was extracted with the $2 \%$ cetyl trimethyl ammonium bromide protocol described by Morlais et al. [46], then resuspended in 1:50 $\mu \mathrm{l}$ sterile water and stored at $-20{ }^{\circ} \mathrm{C}$. The sodium channel gene was examined by PCR and direct sequencing of fragment encoding to verify the presence of mutations at $I 1011 \mathrm{M}$ or $11011 \mathrm{~V}$, V1016G or V1016I and F1534C in Ae. aegypti and F1534C in Ae. albopictus. In Ae. aegypti, we amplified and sequenced a part of segment 6 of domain II with the primers AaSCF1 and AaSCR4 [35] and domain III with AaSCF7 and AaSCR7 [35]. Whereas, Ae. albopictus was amplified with AaSCF7 and AaSCR7 [37] for domain III.

The PCR mixture contained $2.5 \mu \mathrm{l} 10 \times$ buffer (Eurogentec, USA), $1.5 \mathrm{MgCl}_{2}, 1 \mathrm{mM}$ dNTP (Eurogentec, USA), $1 \mu \mathrm{l}$ of $1 / 10$ of each primer, $0.1 \mu \mathrm{l}$ of Diamond Taq DNA polymerase (Eurogentec, USA) and $4 \mu \mathrm{l}$ of $1 / 50$ diluted total DNA in a total volume of $25 \mu$ l. DNA was amplified in a GeneAmp 9600 thermal cycler (PerkinElmer, USA) under the following conditions: $94{ }^{\circ} \mathrm{C}$ for $3 \mathrm{~min}$, followed by 40 cycles of $30 \mathrm{~s}$ at $94{ }^{\circ} \mathrm{C}, 45 \mathrm{~s}$ at the annealing temperature $64{ }^{\circ} \mathrm{C}, 45 \mathrm{~s}$ at $72{ }^{\circ} \mathrm{C}$ and $10 \mathrm{~min}$ at $72{ }^{\circ} \mathrm{C}$. PCR products $(10 \mu \mathrm{l})$ were migrated on $1.5 \%$ agarose gel in TAE buffer, purified with AMPure ${ }^{\circ}$ Agencourt ${ }^{\circ}$ (Beckman Coulter, Danvers MA, USA) when they contained amplified fragments of the expected size and then sequenced with a BigDye Terminator v3.1 Cycle sequencing kit (Applied Biosystems, USA). The primers used for sequencing were: AeSCF3 for $I 1011 M / V$, AeSCR6 for V1016G/I and AeSCR8 for F1534C mutations in Ae. aegypti and AeSCR8 and AeSCR7 for the F1534C mutation in Ae. albopictus.

The sequence reaction was carried out in $9 \mu \mathrm{l}$ of reaction volume containing $1 \mu \mathrm{l}$ of $5 \times$ buffer sequence, $1 \mu \mathrm{l}$ of primer ( $5 \mathrm{pmol}$ ), $1 \mu \mathrm{l}$ of Big Dye terminator V3.1 and $1 \mu \mathrm{l}$ of purified amplicons. Amplification was performed at $96{ }^{\circ} \mathrm{C}$ for $1 \mathrm{~min}$, followed by 25 cycles at $96{ }^{\circ} \mathrm{C}$ for $10 \mathrm{~s}, 50{ }^{\circ} \mathrm{C}$ for $5 \mathrm{~s}$ and $60{ }^{\circ} \mathrm{C}$ for $4 \mathrm{~min}$. Direct DNA sequencing was performed on an automatic sequencer ABI 3130XL (Applied BioSystems). Sequences were analysed with BioEdit version 7.2.5 [47].

\section{Biochemical assays}

In order to detect metabolic resistance, biochemical analyses were performed on 2-3-day-old $F_{0}$ mosquito 
females by the modified microplate methods described by Hemingway \& Karunaratne [48] and Brogdon et al. [49]. None of the mosquitoes used had been exposed to insecticide. For each experiment, at least 25 mosquitoes per species were assayed for MFO, GST, acetylcholinesterase (AChE), $\alpha$ - and $\beta$-esterases and total proteins. The SBE strain was used as the susceptible reference. Two wells filled with $10 \mu \mathrm{l}$ of sterile distilled water were used as background (in two adjacent wells) for each analysis. Mosquitoes were ground individually on ice in $200 \mu \mathrm{l}$ of sterile distilled water. Before centrifugation, $25 \mu$ of each homogenate were distributed in two adjacent wells of a microplate to test for acetylcholinesterase, and the rest of the homogenate was centrifuged at $14,000 \mathrm{rpm}$ for $2 \mathrm{~min}$. Total protein and other enzyme systems were analysed in two replicates. The volume of supernatant was $20 \mu \mathrm{l}$ for MFO and $10 \mu \mathrm{l}$ for GST, $\alpha-$ and $\beta$-esterases and total proteins. Absorbance was measured in a spectrophotometer for microplate readers (TECAN, Sunrise $^{\mathrm{mm}}$ ) with Magellan version 7.0. software.

The ratios of the specific activities of enzymes to the protein content of individual homogenates were determined in the Bradford assay [50]. Thus, $10 \mu \mathrm{l}$ of each homogenate was mixed in a microtitre plate well with $140 \mu \mathrm{l}$ of Bradford reagent (Sigma-Aldrich, St Louis, USA), and the mixture was incubated at room temperature for $5 \mathrm{~min}$. The end-point absorbance was read at $595 \mathrm{~nm}$. Protein values were calculated from a standard curve of absorbance of bovine serum albumin.

\section{Mixed function oxidase assay}

The assay used to measure mixed-function oxidases detects increases in the amount of haem, which are then converted into equivalent units of cytochrome P450. Cytochrome P450 was titrated in the haemperoxidase assay according to Brogdon et al. [49]. Briefly, $80 \mu \mathrm{l}$ of $0.625 \mathrm{M}$ potassium phosphate buffer ( $\mathrm{pH} 7.2)$ were added to $20 \mu \mathrm{l}$ of microfuged supernatant and $200 \mu \mathrm{l}$ of tetramethylbenzidine solution $\left(0.011 \mathrm{~g} \mathrm{3,3} \mathbf{3}^{\prime}, 5,5^{\prime}\right.$ tetramethylbenzidine $+5 \mathrm{ml}$ methanol $+15 \mathrm{ml}$ sodium acetate buffer $0.25 \mathrm{M}, \mathrm{pH} 5.0$ ). After addition of $25 \mu \mathrm{l}$ of $3 \%$ hydrogen peroxide, the mixture was incubated for $15 \mathrm{~min}$ at room temperature with a cover. Absorbance was read at $630 \mathrm{~nm}$ and values calculated from a standard curve.

\section{Glutathione S-transferase assay}

Glutathione $S$-transferase was measured with a $200 \mu \mathrm{l} 1$ chloro-2,4-dinitrobenzene working solution $(100 \mu \mathrm{l}$ of $0.060 \mathrm{~g}$ reduced glutathione prepared in $10 \mathrm{ml} 0.1 \mathrm{M}$ sodium phosphate buffer $\mathrm{pH} 6.5+100 \mu \mathrm{l}$ of $0.013 \mathrm{~g} 63 \mathrm{mM}$ 1-chloro-2,4-dinitrobenzene, diluted in $1 \mathrm{ml}$ methanol and $10 \mathrm{ml} 0.1 \mathrm{M}$ phosphate buffer at $\mathrm{pH} 6.5$ ) added to each replicate of mosquito homogenate. Absorbance was read at $340 \mathrm{~nm}$ every $30 \mathrm{~s}$ for $5 \mathrm{~min}$. The rate of formation of conjugated 1-chloro-2,4-dinitrobenzene was assessed kinetically from a molecular extinction coefficient $\left(9.5\right.$ mM.cm $\left.{ }^{-1}\right)$.

\section{Acetylcholinesterase assay}

Two $25-\mu$ l replicates from each mosquito homogenate were placed in adjacent wells of a microtitre plate. Membrane-bound acetylcholinesterase in the mosquito homogenate was solubilized by adding $145 \mu \mathrm{l}$ of Triton phosphate buffer (1\% (v/v) Triton X-100 in $0.1 \mathrm{M}$ phosphate buffer, $\mathrm{pH}$ 7.8). To one set of homogenates, $25 \mu \mathrm{l}$ of $0.01 \mathrm{M}$ acetylthiocholine iodide (ASChI) and $10 \mu \mathrm{l}$ of $0.1 \mathrm{M}$ propoxur solution $(2.5 \mathrm{ml} 0.1 \mathrm{M} \mathrm{ASChI}+10 \mu \mathrm{l}$ of $0.1 \mathrm{M}$ propoxur in acetone) were added. To the other replicate, $25 \mu \mathrm{l}$ of ASChI alone was added. The preparation was incubated for $3 \mathrm{~min}$ at room temperature, and the kinetics of the enzyme reaction was monitored continuously at $420 \mathrm{~nm}$ for $5 \mathrm{~min}$. The results were expressed as percentage remaining activity in the inhibited fraction and in the control (uninhibited).

\section{Esterase assays}

Non-specific esterase activity was assessed with two substrates, $\alpha$ - and $\beta$-naphthol acetate. For both substrates, $90 \mu \mathrm{l}$ of phosphate buffer saline $(\mathrm{pH}$ 6.5) containing $1 \%$ Triton were added to the plate well containing $10 \mu \mathrm{l}$ of microfuge supernatant, and the reactions were incubated at ambient temperature for $10 \mathrm{~min}$, when $100 \mu \mathrm{l} 0.6 \mathrm{M}$ naphthol was added. After $30 \mathrm{~min}$ incubation at ambient temperature, $100 \mu \mathrm{l}$ of Fast Garnett BC solution $(0.010 \mathrm{~g}$ Fast Garnett salt $+12 \mathrm{ml}$ distilled water) were added to stop the reaction. The reaction was then incubated for $10 \mathrm{~min}$ at room temperature. The concentration of the final product was determined at $550 \mathrm{~nm}$ calculated from a standard curve of $\alpha$ - or $\beta$-naphthol. Esterasespecific activity per individual was reported as $\mu \mathrm{mol}$ product. $\mathrm{min}^{-1} \cdot \mathrm{mg}^{-1}$ protein.

\section{Biochemical data analysis}

Mean absorbance values of replicate wells for each tested mosquito were converted into enzyme activity and divided by the protein values. The mean activity of each sample was calculated and the distributions of enzymatic activities from wild mosquitoes were compared to those of reference strain mosquitoes (Ae. aegypti $\mathrm{SBE}$ ) using Mann-Whitney tests (nonparametric) with GraphPad Prism version 5.00 software and Mann-Withney U-test with MedCalc version 15. Statistical significance was assumed at $P<0.05$. Mann-Whitney test or Kruskal-Wallis test as appropriated was performed with STATA/IC version 11 (StataCorp College Station, Texas 77845) to assess the association between resistance status and enzymes 
activities in wild specimens but also to the reference strain, and $P$-values $<0.05$ were considered statistically significant.

\section{Results}

\section{Susceptibility to larvicides}

Aedes aegypti and Ae. albopictus larvae from all sites were susceptible to both larvicides, Bti and temephos (Tables 1 and 2). For Ae. aegypti, the $\mathrm{LC}_{50}$ of Bti was $0.06-0.15 \mathrm{mg} / \mathrm{l}$ and the $\mathrm{LC}_{95} 0.25-0.30 \mathrm{mg} / \mathrm{l}$, with similar results in Ae. albopictus ( $\mathrm{LC}_{50}, 0.07-0.11 \mathrm{mg} / \mathrm{l}$ and $\left.\mathrm{LC}_{95}, 0.20-0.27 \mathrm{mg} / \mathrm{l}\right)$. For temephos, the $\mathrm{LC}_{50}$ in $A e$. aegypti was $0.0049-0.0059 \mathrm{mg} / \mathrm{l}$ and the $\mathrm{LC}_{95} 0.0076-$ $0.0096 \mathrm{mg} / \mathrm{l}$, with values in Ae albopictus of $0.0042-$ $0.0057 \mathrm{mg} / \mathrm{l}$ and $0.0066-0.01 \mathrm{mg} / \mathrm{l}$, respectively.

\section{Susceptibility to adulticides}

The results of WHO tube tests on Ae. aegypti and Ae. albopictus collected in six districts of Bangui are presented in Table 3. The mortality rate of negative controls was $<5 \%$. In Ae. aegypti, resistance to DDT was observed in four populations, with mortality rates of $71-80 \%$, and probable resistance in two further populations, with mortality rates of 93 and $94 \%$. Only one population of $\mathrm{Ae}$. albopictus was susceptible (100\% mortality) and the rest was either suspected to be resistant (95-97\% mortality) or resistant (41-90\% mortality). With deltamethrin, Ae. aegypti from three localities showed mortality rates $\geq$ $98 \%$, while the rates in other populations were between 95 and $97 \%$. Samples of Ae. albopictus collected at two sites were resistant (rates of 87 and 94\%), while all other populations were sensitive. Bioassays with propoxur and fenitrothion showed full susceptibility of the populations of both species, except for one population of Ae. albopictus to propoxur (mortality rate of $94 \%$ ) and one of $A e$. albopictus to fenitrothion (mortality rate of 96.4\%).

\section{Knockdown time}

The $\mathrm{KDT}_{50}$ calculated after exposure to DDT ranged from 35 to $80 \mathrm{~min}$ for Ae aegypti and from 31 to $81.4 \mathrm{~min}$ for Ae. albopictus (Table 4). The resistance ratio at $\mathrm{KDT}_{50}$ for DDT was increased for populations of both species considered as resistant based on their mortality rates. However, these increases were rather limited and ratios did not exceed 1.6. With deltamethrin, all the $\mathrm{KDT}_{50}$ values for both species were $<30 \mathrm{~min}$, and the resistance ratio at $\mathrm{KDT}_{50}$ was also increased for some populations considered as possibly resistant but ratios were low and below 2 .

\section{Genotyping of $k d r$ mutations}

We analysed 80 Ae. aegypti and 93 Ae. albopictus specimens that were survivors of the adult bioassays. None of the non-synonymous mutations in the voltage-gated sensitive channel was detected.

\section{Biochemical assays}

For each of the four enzyme systems tested, we analysed at least 25 individuals per species and per population (Figs. 2 and 3). Comparisons with the SBE strain showed significant differences (Mann-Whitney $U$-test, $P<0.05$ ) in mean enzyme activity in some populations: $\alpha$-esterase activities were significantly higher in two Ae. albopictus populations (IPB, $U=140, Z=4.84, P<0.0001$, and Sica $1, U=216, Z=3.32$, $P=0.0009$ ), and $\beta$-esterase activities were significantly

Table 1 Larval bioassays with Bacillus thuringensis israelensis against Aedes aegypti and Ae. albopictus larvae

\begin{tabular}{|c|c|c|c|c|c|}
\hline Strain and site & $n$ & $\mathrm{LC}_{50}(\mathrm{mg} / \mathrm{l})(95 \% \mathrm{Cl})$ & $\mathrm{LC}_{95}(\mathrm{mg} / \mathrm{l})(95 \% \mathrm{Cl})$ & $\mathrm{RR}_{50}$ & $\mathrm{RR}_{95}$ \\
\hline \multicolumn{6}{|l|}{ Ae. aegypti } \\
\hline IPB & 500 & $0.06(0.05-0.08)$ & $0.27(0.22-0.38)$ & 0.85 & 1.58 \\
\hline Sica 1 & 500 & $0.07(0.04-0.09)$ & $0.25(0.20-0.35)$ & 1.00 & 1.47 \\
\hline Lakouanga & 500 & $0.15(0.12-0.16)$ & $0.30(0.26-0.42)$ & 1.85 & 1.57 \\
\hline Ouango & 498 & $0.06(0.05-0.09)$ & $0.25(0.20-0.37)$ & 0.85 & 1.47 \\
\hline Ngongonon 3 & 500 & $0.08(0.06-0.10)$ & $0.27(0.22-0.36)$ & 1.14 & 1.58 \\
\hline 92 Logements & na & - & - & & \\
\hline \multicolumn{6}{|l|}{ Ae. albopictus } \\
\hline IPB & 500 & $0.09(0.06-0.12)$ & $0.21(0.18-0.23)$ & 1.28 & 1.23 \\
\hline Sica 1 & 500 & $0.08(0.05-0.10)$ & $0.27(0.22-0.37)$ & 1.14 & 1.58 \\
\hline Lakouanga & 500 & $0.11(0.07-0.16)$ & $0.26(0.21-0.32)$ & 1.57 & 1.52 \\
\hline Ouango & 500 & $0.07(0.05-0.09)$ & $0.23(0.19-0.30)$ & 1.00 & 1.35 \\
\hline Ngongonon 3 & 500 & $0.10(0.07-0.11)$ & $0.2(0.20-0.27)$ & 1.42 & 1.17 \\
\hline 92 Logements & na & - & - & & \\
\hline Reference strain & 500 & $0.07(0.05-0.08)$ & $0.17(0.15-0.21)$ & & \\
\hline
\end{tabular}

Abbreviations: $n a$ not available; $\mathrm{LC}_{50}$ and $\mathrm{LC}_{95}, 50$ and $95 \%$ lethal concentrations; $\mathrm{Cl}$ Confidence interval, $R R$ Resistance ratio 
Table $\mathbf{2}$ Larval bioassays with temephos against Aedes aegypti and Ae. albopictus larvae

\begin{tabular}{|c|c|c|c|c|c|}
\hline Strain and site & $n$ & $\mathrm{LC}_{50}(\mathrm{mg} / \mathrm{l})(95 \% \mathrm{Cl})$ & $\mathrm{LC}_{95}(\mathrm{mg} / \mathrm{l})(95 \% \mathrm{Cl})$ & $\mathrm{RR}_{50}$ & $\mathrm{RR}_{95}$ \\
\hline \multicolumn{6}{|l|}{ Ae. aegypti } \\
\hline IPB & 800 & $0.0055(0.0047-0.0060)$ & $0.0089(0.0084-0.0098)$ & 1.17 & 1.21 \\
\hline Sica 1 & 800 & $0.0059(0.0052-0.0064)$ & $0.0096(0.0089-0.0108)$ & 1.25 & 1.31 \\
\hline Lakouanga & 800 & $0.0054(0.0043-0.0063)$ & $0.0076(0.0068-0.0082)$ & 1.14 & 1.04 \\
\hline Ouango & 790 & $0.0052(0.0046-0.0061)$ & $0.0082(0.0076-0.0091)$ & 1.10 & 1.12 \\
\hline Ngongonon 3 & 788 & $0.0049(0.0035-0.0057)$ & $0.0079(0.0073-0.0085)$ & 1.08 & 1.08 \\
\hline 92 Logements & 782 & $0.0057(0.0038-0.0061)$ & $00095(0.0080-0.0093)$ & 1.21 & 1.30 \\
\hline \multicolumn{6}{|l|}{ Ae. albopictus } \\
\hline IPB & 800 & $0.0050(0.0014-0.0063)$ & $0.0091(0.0083-0.0148)$ & 1.06 & 1.24 \\
\hline Sica 1 & 800 & $0.0050(0.0012-0.0068)$ & $0.01(0.078-0.0127)$ & 1.06 & 1.36 \\
\hline Lakouanga & 797 & 0.0055 (0.0047-0063) & $0.0082(0.0077-0.0133)$ & 1.17 & 1.12 \\
\hline Ouango & 769 & $0.0048(0.0037-0.0058)$ & $0.0078(0.0067-0.0084)$ & 1.02 & 1.06 \\
\hline Ngongonon 3 & 800 & $0.0057(0.0046-0.0063)$ & $0.0098(0.0091-0.011)$ & 1.21 & 1.34 \\
\hline 92 Logements & 788 & $0.0042(0.0034-0.0054)$ & $0.0066(0.0055-0.0078)$ & 0.89 & 0.90 \\
\hline Reference strain & 800 & $0.0047(0.0020-0.0108)$ & $0.0073(0.0055-0.0097)$ & & \\
\hline
\end{tabular}

Abbreviations: $\mathrm{LC}_{50}$ and $\mathrm{LC}_{95}, 50$ and $95 \%$ lethal concentrations; $\mathrm{Cl}$ Confidence interval, $R R$ Resistance ratio

higher in all five populations of Ae. aegypti (IPB, $U=429.5$, $Z=1.98, \quad P=0.04 ; \quad$ Sica $1, \quad U=284, \quad Z=2.3, \quad P=0.02$; Lakouanga, $U=258, Z=2.69, P=0.007$; Ouango, $U=$ 214.5, $Z=3.34, P=0.0008$; and Ngongonon 3, $U=230.5$, $Z=3.1, P=0.001)$ and three Ae. albopictus populations (IPB, $U=118, Z=5.14, P<0.0001$; Sica $1, U=84, Z=$
5.3, $P<0.0001$; and Lakouanga, $U=168, Z=4.04, P=$ 0.0001 .

Significantly higher MFO activity was observed in three Ae. aegypti populations (IPB, $U=404, Z=2.29$, $P=0.02$; Ouango, $U=296, Z=2.12, P=0.03$; and Ngongonon $3, \quad U=296.5, \quad Z=2.11, \quad P=0.03)$ and two Ae.

Table 3 Mortality rates of adult Aedes aegypti and Ae. albopictus from Bangui and neighbourhoods $24 \mathrm{~h}$ after exposure to insecticides

\begin{tabular}{|c|c|c|c|c|c|c|c|c|}
\hline \multirow[t]{3}{*}{ Species and site } & \multicolumn{8}{|c|}{ \% mortality (no. of mosquitoes assayed) } \\
\hline & \multicolumn{2}{|c|}{ Organochlorine } & \multicolumn{2}{|l|}{ Pyrethroid } & \multicolumn{2}{|l|}{ Carbamate } & \multicolumn{2}{|l|}{ Organophosphate } \\
\hline & $4 \%$ DDT & Status & $0.05 \%$ deltamethrin & Status & $0.1 \%$ propoxur & Status & $0.5 \%$ fenitrothion & Status \\
\hline \multicolumn{9}{|l|}{ Ae. aegypti } \\
\hline IPB & $71.5(88)$ & $\mathrm{R}$ & $95.4(88)$ & RS & $99(100)$ & S & $100(88)$ & S \\
\hline Sica 1 & $78(100)$ & $\mathrm{R}$ & $95.6(93)$ & RS & $100(100)$ & S & $100(100)$ & S \\
\hline Lakouanga & $79.5(93)$ & $\mathrm{R}$ & $98(100)$ & S & $100(100)$ & $\mathrm{S}$ & $100(100)$ & S \\
\hline Ouango & $93.4(92)$ & RS & $100(50)$ & S & $98(50)$ & S & $100(100)$ & S \\
\hline Ngongonon 3 & $94(100)$ & RS & $97(100)$ & RS & $100(99)$ & S & $100(88)$ & S \\
\hline 92 Logements & $78(50)$ & R & $100(100)$ & S & $100(50)$ & S & na & - \\
\hline \multicolumn{9}{|l|}{ Ae. albopictus } \\
\hline IPB & $96.2(79)$ & RS & $100(100)$ & S & $100(75)$ & S & $100(89)$ & S \\
\hline Sica 1 & $80.2(96)$ & $\mathrm{R}$ & $87(100)$ & RS & $99(98)$ & S & $100(93)$ & S \\
\hline Lakouanga & $95.7(71)$ & RS & $99(89)$ & S & $100(94)$ & S & $100(100)$ & S \\
\hline Ouango & $90(97)$ & $\mathrm{R}$ & $99(97)$ & S & $100(100)$ & S & $100(100)$ & S \\
\hline Ngongonon 3 & $100(80)$ & S & $100(93)$ & S & $100(84)$ & S & $96.4(84)$ & RS \\
\hline 92 Logements & $41(100)$ & $\mathrm{R}$ & $94(100)$ & RS & $94(50)$ & RS & $100(100)$ & S \\
\hline Reference strain & 100 (100) & & $100(100)$ & & $100(100)$ & & $100(100)$ & \\
\hline
\end{tabular}


Table 4 Knockdown times in minutes of Aedes aegypti and Ae. albopictus exposed to 4\% DDT and 0.05\% deltamethrin. Estimates are from probit analyses with 95\% confidence intervals (CI). Resistance ratios (RRs) are calculated as the ratio of the KDT $\mathbf{5 0}_{\mathbf{0}}$ of the field population to that of the control population

\begin{tabular}{|c|c|c|c|c|c|c|c|}
\hline \multirow[t]{2}{*}{ Insecticide } & \multirow[t]{2}{*}{ Site } & \multicolumn{3}{|l|}{ Ae. aegypti } & \multicolumn{3}{|l|}{ Ae. albopictus } \\
\hline & & $\mathrm{KDT}_{50}(95 \% \mathrm{Cl})$ & $\mathrm{KDT}_{95}(95 \% \mathrm{Cl})$ & $\mathrm{KDT}_{50}$ ratio $(\mathrm{RR})$ & $\mathrm{KDT}_{50}(95 \% \mathrm{Cl})$ & $\mathrm{KDT}_{95}(95 \%$ I Cl) & $\mathrm{KDT}_{50}$ ratio $(\mathrm{RR})$ \\
\hline \multicolumn{8}{|l|}{$4 \%$ DDT } \\
\hline & IPB & $63(57.6-71.9)$ & $115.6(100.7-139.2)$ & 1.2 & $46.5(43.2-50.7)$ & $91.4(82.1-104.8)$ & 1 \\
\hline & Sica 1 & $55.5(53.4-58.1)$ & $85.2(80.0-92.1)$ & 1.1 & $81.4(70.0-103.5)$ & $133.0(109.1-180.7)$ & 1.6 \\
\hline & Lakouanga & $61.2(57.9-65.5)$ & $98.0(90.1-108.8)$ & 1.2 & $48.0(46.1-50.3)$ & $71.4(67.0-77.3)$ & 1 \\
\hline & Ouango & $34.6(32.6-36.5)$ & $61.1(57.4-65.7)$ & 0.7 & $76.6(65.1-98.0)$ & $172.0(138.0-237.5)$ & 1.5 \\
\hline & Ngongonon 3 & $40.4(39.3-41.6)$ & $60.1(57.9-62.6)$ & 0.8 & $30.5(27.8-33.3)$ & $57.4(52.2-64.8)$ & 0.6 \\
\hline & 92 Logements & 79.8 (69.9-98.5) & $127.6(106.3-169.5)$ & 1.6 & $65.5(60.6-78.8)$ & $80.7(71.1-108.1)$ & 1.3 \\
\hline & Reference strain & $50.2(47.3-52.2)$ & 90.4 (85.3-94.) & 1 & - & - & \\
\hline \multicolumn{8}{|c|}{ 0.05\% deltamethrin } \\
\hline & IPB & 14.8(11.9-15.2) & $23.5(21.3-25.8)$ & 1.1 & $15.8(8.1-21.5)$ & $27.8(21.9-48.7)$ & 1.2 \\
\hline & Sica 1 & $21.2(14.9-26.3)$ & $40(34.2-54.5)$ & 1.6 & $26.8(18.2-33.6)$ & $54.9(45.4-77.2)$ & 2 \\
\hline & Lakouanga & $12.1(10.7-14.7)$ & $27.4(24.8-29.7)$ & 1 & $14.3(11.8-16.1)$ & $23.5(18-38.1)$ & 1.1 \\
\hline & Ouango & $23.1(20.3-25.7)$ & $42.01(38.0-47.7)$ & 1.7 & $10.1(4.4-13.6)$ & $24.0(19.5-34.3)$ & 0.8 \\
\hline & Ngongonon 3 & $14.1(12.1-15.9)$ & $26.3(23.6-0.4)$ & 1.1 & $13.9(12.5-15.2)$ & $28.1(26.0-31.0)$ & 1 \\
\hline & 92 Logements & $18.6(17.8-19.5)$ & $29.3(27.9-30.9)$ & 1.4 & $23.6(13.8-30.9)$ & $45.0(36.4-67.7)$ & 1.8 \\
\hline & Reference strain & $13.4(10.2-14.6)$ & $24.8(22.3-24.1)$ & 1 & - & - & \\
\hline
\end{tabular}

albopictus populations (IPB, $U=66, Z=5.86, P<0.0001$ and Sica $1, U=264, Z=2.6, P=0.009)$. The mean rate of inhibition of AChE activity in the presence of propoxur was significantly lower in two Ae. aegypti populations (Lakouanga, $U=191, Z=3.69, P=0.0002$ and Ouango, $U$ $=206, Z=3.47, P=0.0005)$ and in two Ae. albopictus populations (Lakouanga, $U=205, Z=3.48, P=0.0005$ and 92 Logements, $U=92, Z=5.18, P<0.0001$ ), suggesting that they contained some individuals with reduced sensitivity. Glutathione $S$-transferase activity was significantly higher than control in two populations of Ae aegypti (Ouango, $U=155.5, Z=4.22, P<0.0001$ and Ngongonon $3, U=295$, $Z=2.13, P=0.03)$ and in three populations of Ae. albopictus (IPB, $U=223, Z=3.69, P=0.0002$, Sica $1, U=$ 287, $Z=2.25, P=0.024$ and 92 Logements, $U=156.5$, $Z=4.24, P<0.0001)$. Statistical analysis performed to assess association between enzyme activities and resistance status of Aedes spp. populations. This showed that resistance status is significantly associated to certain enzyme activities such as GST and CytP450 in Ae. aegypti (Additional file 1: Table S1), and EST ( $\alpha$ - and $\beta-$ ), GST and CytP450 in Ae. albopictus (Additional file 1: Table S2). This showed also that enzyme activities of field strain in both Aedes spp. is generally high than those of susceptible laboratory strains.

\section{Discussion}

The results of the larval bioassays with $B t i$ and temephos indicated satisfactory susceptibility in all samples of $A e$. aegypti and Ae. albopictus assayed. Full resistance to Bti has not been reported in field populations of either Aedes species although it was found in Culex pipiens in New York State [51]. This larvicide acts as a mixture of toxins with different modes of action, which reduces resistance in targeted populations. As Bti is highly specific to some Diptera and might be considered a biological control agent, it is the first choice of larvicide for use against Aedes species [39, 52]. For temephos, our results suggest full susceptibility of all the tested populations. Nevertheless, resistance to this compound has been reported in Ae. aegypti in Brazil [53] and Santiago Island in Cape Verde [54] and in Ae. albopictus in Greece [55]. Insecticide resistance results from extensive, long-term use [20, 21]; thus, for example, in Brazil, resistance to temephos compromises its use by the national dengue control programme $[56,57]$. Although this insecticide was used moderately in Central Africa (Cameroon and Gabon) in the 1970s [38], it had never been used in vector control programmes in CAR, which probably explains the full susceptibility we observed for both species.

None of the Ae. aegypti populations from Bangui can be considered fully susceptible to DDT, as all were either possibly resistant or resistant. The same was true for Ae. albopictus, although the mortality rates were sometimes lower (41\%). Mouchet et al. [38] previously reported decreased susceptibility to DDT in Ae. aegypti sampled in Bangui in 1965 and 1971, suggesting continuing 


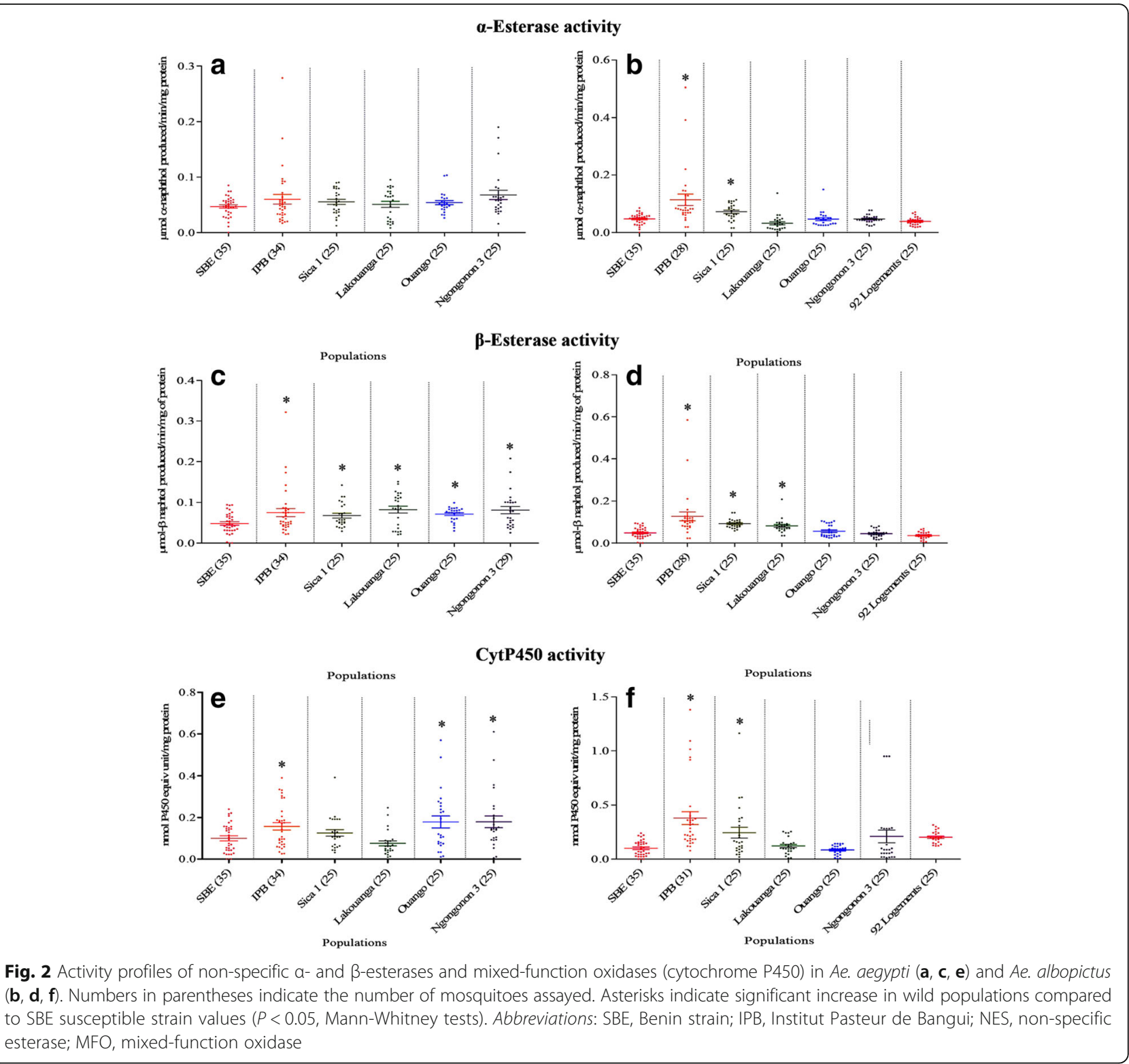

selection pressure on Aedes populations. DDT resistance has repeatedly been reported in Ae. aegypti $[24,58]$ and Ae. albopictus $[59,60]$, although data for the latter are scarce. The decreased susceptibility to deltamethrin observed in both populations may represent an obstacle for vector control programmes, because pyrethroids are recommended for the control of adult Aedes mosquitoes $[61,62]$.

The resistance to DDT and deltamethrin observed in both species is difficult to explain, because in CAR, as in other countries of Central Africa, use of insecticides against Ae. aegypti and Ae. albopictus is limited [39]. CAR has promoted use of long-lasting insecticidal nets as one of the main components of the national malaria control programme, with indoor residual spraying by households with insecticides available on the market, which we noted at nearly every study site. Therefore, insecticides used against other insects of medical or agricultural importance may exert indirect selection pressure on these two mosquito species [63, 64]. Similar observations have been made for resistance of Ae. aegypti to deltamethrin in Indonesia [65], Thailand [61] and Nigeria [58]. As Ae. albopictus was reported for the first time in CAR in 2009 [66], we cannot exclude the possibility of invading populations with resistance to DDT, as suggested by Kamgang et al. [39] in Cameroon.

In this study, the $k d r$ mutations $I 1011 M / V, V 1016 G / I$, F1534C in Ae. aegypti and F1534C in Ae. albopictus were not detected in mosquitoes that survived to DDT or deltamethrin, in accordance with the finding that knockdown 


\section{AChE activity}
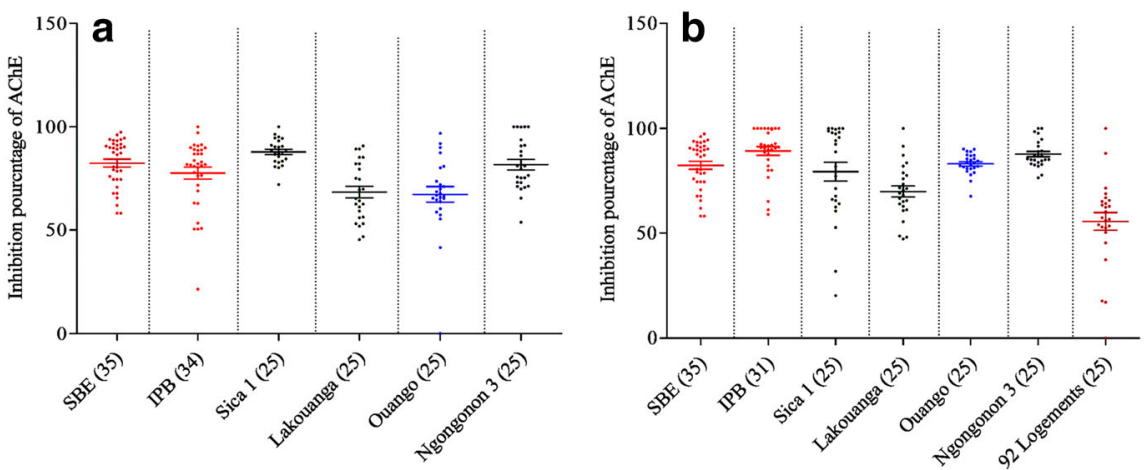

GST activity
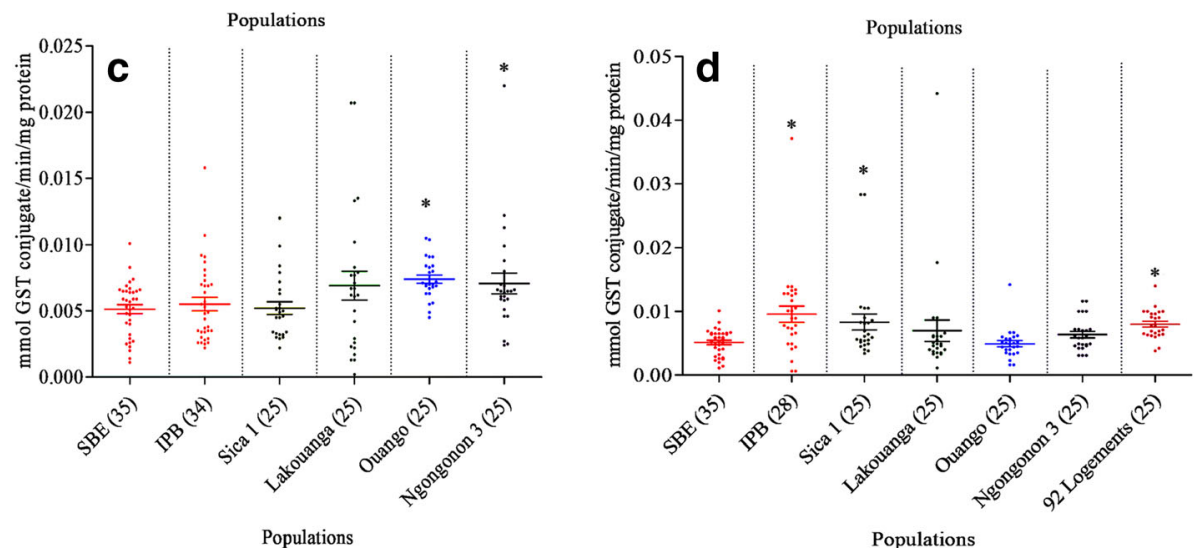

Fig. 3 Profiles of acetylcholinesterase inhibition and glutathione S-transferase in Ae. aegypti $(\mathbf{a}, \mathbf{c})$ and Ae. albopictus (b, d). Numbers in parentheses indicate the number of mosquitoes assayed. Asterisks indicate significant differences compared to SBE susceptible strain values $(P<0.05$, Mann-Whitney tests). Abbreviations: SBE, Benin strain; IPB, Institut Pasteur de Bangui; AChE, acetylcholinesterase; GST, glutathione S-transferase

time was not or weakly increased during insecticide exposure in test tubes. We observed increased activity of several enzymes in Ae. aegypti and Ae. albopictus samples that might explain the decreased susceptibility to DDT and pyrethroids. Although the mean activity of $\beta$-esterase was increased significantly in some populations of $A e$. aegypti and Ae. albopictus, there was no evidence of resistance to deltamethrin in these samples according to $\mathrm{WHO}$ diagnostic concentrations [42]; however, most of the WHO diagnostic concentrations were established for Anopheles species, and it is possible that they are not transposable to Aedes or Culex mosquitoes. The diagnostic concentrations on these species for the main insecticides used in control vector should therefore be assessed. Although elevated esterase and glutathione $S$-transferase activities can be involved in temephos resistance [67], in our study all the populations were fully susceptible to this insecticide.

High MFO activity was found in three Ae. aegypti and three Ae. albopictus populations, but also with no clear association with full resistance to deltamethrin. In contrast, Paeporn et al. [68] in Thailand showed that increased MFO and esterase activities in Ae. aegypti strains were associated with pyrethroid (deltamethrin and permethrin) resistance, and Saavedra-Rodriguez et al. [69] reported that mixed-function oxidases and esterases were important in resistance to organophosphate insecticides in Ae. aegypti populations in Latin America. Reduced activity of AChE to propoxur inhibition was detected in some individuals of Ae. aegypti and Ae. albopictus, suggesting possible emergence of resistance to carbamates or other organophosphates in field populations.

\section{Conclusion}

We describe for the first time the susceptibility of Aedes in CAR to the main insecticide classes and the mechanisms potentially involved in resistance. This information adds to that on the susceptibility of Ae. aegypti and Ae. albopictus to commonly used insecticides in Central Africa. The susceptibility of both species to Bti and temephos is encouraging for larval control in Bangui; however, most Ae. aegypti and Ae. albopictus samples were resistant or suspected of being resistant to DDT. Moreover, some 
populations of both species showed possible resistance to deltamethrin according to the WHO criteria. The absence of $k d r$ mutations in the two species cannot explain the decreased sensitivity; however, differences in the activity of certain enzymes involved in metabolism could explain differences in susceptibility between populations. The results with propoxur (carbamate) and fenitrothion (organophosphate) were satisfactory, as decreased sensitivity was found in only one population of Ae. albopictus for propoxur and one for fenitrothion. These findings are important for effective control of DENV, CHIKV and ZIKV vectors in CAR. Further studies with the Centers for Disease Control and Prevention bottle bioassay and synergists should be conducted to obtain additional information on metabolic-mediated resistance mechanisms.

\section{Additional files}

Additional file 1: Table S1. Assessing association between resistance status and enzyme activities in Ae. aegypti. Table S2. Assessing association between resistance status and enzyme activities in Ae. abopictus. (DOC 135 kb)

\section{Abbreviations \\ ASChl: Acetylthiocholine iodide; Bti: Bacillus thuringiensis var israeliensis; CAR: Central African Republic; CHIKV: Virus of chikungunya; Cls: Confidence intervals; DDT: Dichlorodiphenyltrichloroethane; DENV: Virus of dengue; DNA: Deoxyribonucleic acid; dNTP: Deoxyribonucleotide triphosphate; GST: Glutathione S-transferase; IPB: Institut Pasteur de Bangui; Kd: Knockdown; Kdr: Knockdown resistance; KDT: Knockdown time; LC: Lethal concentration; MFO: Mixed-function oxidase; NA: Not available; NES: Non-specific esterase; PCR: Polymerase chain reaction; rpm: Rotations (or revolutions) per minute; RR: resistance ratio; SBE: Strain from Benin; TAE: Tris-acetate-EDTA; WHO: World Health Organization}

\section{Acknowledgements}

We thank Marie Rossignol (MIVEGEC, IRD) for assistance in the larval bioassays and Marina Olé Sangba-Zélo and Claire Sangba-Kembi Ngounou for assistance in mosquito sampling. We also thank Alexandre Manirakiza from the IPB for assistance in the statistical analysis.

\section{Funding}

This work was supported by the Institute Pasteur de Bangui, the International Network of Pasteur Institutes (Actions Concertées Inter-Pasteuriennes No. A12-12 and A22-15) financed by the Institut Pasteur (Paris, France) and by the Service de Coopération et d'Action Culturelle de l'Ambassade de France à Bangui. The funders had no role in study design, data collection or analysis, decision to publish or preparation of the manuscript.

\section{Availability of data and material}

The datasets supporting the conclusions of this article are included within the article and its additional files

\section{Author's contributions}

$\mathrm{CN}, \mathrm{BK}, \mathrm{CB}$ and GY conceived and designed the experiments; $\mathrm{CN}, \mathrm{CB}, \mathrm{GY}$ performed the experiments; CN, BK, CB and FC analysed the data; CN, FC, EN and MK contributed reagents, materials and analysis tools; and CN, BK, CP and FC wrote the paper. All authors read and approved the final version of the manuscript.

\section{Competing interests}

The authors declare that they have no competing interests.

\section{Consent for publication}

Not applicable.
Ethics approval and consent to participate

Not applicable.

\section{Author details}

'Institut Pasteur de Bangui, PO Box 923, Bangui, Central African Republic ${ }^{2}$ Research Unit Liverpool School of Tropical Medicine, Organisation de Coordination pour la lutte contre les Endémies en Afrique Centrale, PO Box 288, Yaoundé, Cameroon. 'Laboratoire des Maladies Infectieuses et Vecteurs: Ecologie, Génétique, Evolution et Contrôle, Unité mixte de Recherche 2245290, Centre National de Recherche Scientifique-Institut de Recherche pour le Développement, Université de Montpellier, Montpellier, France. ${ }^{4}$ Institut Pasteur de la Guyane, BP 6010, 23 Avenue Pasteur, 97306 Cayenne, French Guiana.

Received: 20 April 2016 Accepted: 14 November 2016

Published online: 24 November 2016

\section{References}

1. Bhatt S, Gething PW, Brady OJ, Messina JP, Farlow AW, Moyes CL, et al. The global distribution and burden of denque. Nature. 2013:496(7446):504-7.

2. Higgs S, Vanlandingham DL. Chikungunya: here today, where tomorrow? Int Health. 2015;7(1):1-3.

3. Pialoux G, Gauzere BA, Jaureguiberry S, Strobel M. Chikungunya, an epidemic arbovirosis. Lancet Infect Dis. 2007:7(5):319-27.

4. Economopoulou A, Dominguez M, Helynck B, Sissoko D, Wichmann O, Quenel P, et al. Atypical Chikungunya virus infections: clinical manifestations, mortality and risk factors for severe disease during the 2005-2006 outbreak on Reunion. Epidemiol Infect. 2009;137(4):534-41.

5. Dick GW, Kitchen SF, Haddow AJ. Zika virus. I. Isolation and serogical specificity. Trans R Soc Trop Med Hyg. 1952;46:509-20.

6. Grard G, Caron M, Mombo IM, Nkoghe D, Mboui Ondo S, Jiolle D, et al. Zika virus in Gabon (Central Africa)-2007: a new threat from Aedes albopictus? PLoS Negl Trop Dis. 2014;8(2):e2681.

7. Duffy MR, Chen TH, Hancock WT, Powers AM, Kool JL, Lanciotti RS, et al. Zika virus outbreak on Yap Island, Federated States of Micronesia. N Engl J Med. 2009;360(24):2536-43.

8. Musso D, Nilles EJ, Cao-Lormeau VM. Rapid spread of emerging Zika virus in the Pacific area. Clin Microbiol Infect. 2014;20(10):0595-6.

9. Scully C, Robinson A. Check before you travel: Zika virus - another emerging global health threat. Br Dent J. 2016;220(5):265-7.

10. WHO: WHO statement on the first meeting of the International Health Regulations (2005) (IHR 2005) Emergency Committee on Zika virus and observed increase in neurological disorders and neonatal malformations (1 February 2016). Geneva: World Health Organization; 2016.

11. Fontenille D, Toto JC. Aedes (Stegomyia) albopictus (Skuse), a potential new Dengue vector in southern Cameroon. Emerg Infect Dis. 2001;7(6):1066-7.

12. Peyrefitte CN, Rousset D, Pastorino BA, Pouillot R, Bessaud M, Tock F, et al. Chikungunya virus, Cameroon, 2006. Emerg Infect Dis. 2007;13(5):768-71.

13. Mombouli JV, Bitsindou P, Elion DO, Grolla A, Feldmann H, Niama FR, et al. Chikungunya virus infection, Brazzaville, Republic of Congo, 2011. Emerg Infect Dis. 2013;19(9):1542-3.

14. Caron M, Paupy C, Grard G, Becquart P, Mombo I, Nso BB, et al. Recent introduction and rapid dissemination of Chikungunya virus and Dengue virus serotype 2 associated with human and mosquito coinfections in Gabon, central Africa. Clin Infect Dis. 2012;55(6):e45-53.

15. Ngoagouni C, Kamgang B, Nakoune E, Paupy C, Kazanji M. Invasion of Aedes albopictus (Diptera: Culicidae) into central Africa: what consequences for emerging diseases? Parasit Vectors. 2015;8:191.

16. Gubler DJ. Dengue and dengue hemorrhagic fever. Clin Microbiol Rev. 1998;11(3):480-96.

17. Chuaycharoensuk T, Juntarajumnong W, Boonyuan W, Bangs MJ, Akratanakul P, Thammapalo $S$, et al. Frequency of pyrethroid resistance in Aedes aegypti and Aedes albopictus (Diptera: Culicidae) in Thailand. J Vector Ecol. 2011;36(1):204-12.

18. Nkya TE, Akhouayri I, Kisinza W, David JP. Impact of environment on mosquito response to pyrethroid insecticides: facts, evidences and prospects. Insect Biochem Mol Biol. 2013;43(4):407-16.

19. WHO. WHOPES-recommended compounds and formulations for control of mosquito larvae. 2016 
20. Hemingway J, Hawkes NJ, McCarroll L, Ranson H. The molecular basis of insecticide resistance in mosquitoes. Insect Biochem Mol Biol. 2004;34(7):653-65.

21. Yadouleton A, Martin T, Padonou G, Chandre F, Asidi A, Djogbenou L, et al. Cotton pest management practices and the selection of pyrethroid resistance in Anopheles gambiae population in Northern Benin. Parasit Vectors. 2011;8:60.

22. Labbé $P$, Alout $H$, Djogbénou $L$, Weill $M$, Pasteur N. Evolution of resistance to insecticide in disease vectors. In: Tibayrenc $M$, ed. Genetics and evolution of infectious disease. London: Elsevier; 2011. p. 363-409.

23. Dusfour I, Zorrilla P, Guidez A, Issaly J, Girod R, Guillaumot L, et al. Deltamethrin resistance mechanisms in Aedes aegypti populations from three French overseas territories worldwide. PLoS Negl Trop Dis. 2015;9(11):e0004226.

24. Ishak IH, Jaal Z, Ranson H, Wondji CS. Contrasting patterns of insecticide resistance and knockdown resistance $(\mathrm{kdr})$ in the dengue vectors Aedes aegypti and Aedes albopictus from Malaysia. Parasit Vectors. 2015;8:181.

25. Davies TG, Field LM, Usherwood PN, Williamson MS. DDT, pyrethrins, pyrethroids and insect sodium channels. IUBMB Life. 2007;59(3):151-62.

26. Martinez-Torres D, Chandre F, Williamson MS, Darriet F, Berge JB, Devonshire AL, et al. Molecular characterization of pyrethroid knockdown resistance $(\mathrm{kdr})$ in the major malaria vector Anopheles gambiae s.s. Insect Mol Biol. 1998;7(2):179-84.

27. Enayati AA, Vatandoost H, Ladonni H, Townson H, Hemingway J. Molecular evidence for a kdr-like pyrethroid resistance mechanism in the malaria vector mosquito Anopheles stephensi. Med Vet Entomol. 2003;17(2):138-44.

28. Martinez-Torres D, Chevillon C, Brun-Barale A, Berge JB, Pasteur N, Pauron D. Voltage-dependent $\mathrm{Na}+$ channels in pyrethroid-resistant Culex pipiens $\mathrm{L}$. mosquitoes. Pest Sci. 1999;55:1012-20.

29. Brengues C, Hawkes NJ, Chandre F, McCarroll L, Duchon S, Guillet P, et al. Pyrethroid and DDT cross-resistance in Aedes aegypti is correlated with novel mutations in the voltage-gated sodium channel gene. Med Vet Entomol. 2003;17(1):87-94.

30. Sayono S, Hidayati AP, Fahri S, Sumanto D, Dharmana E, Hadisaputro S, et al. Distribution of voltage-gated sodium channel (Nav) alleles among the Aedes aegypti populations in central Java province and its association with resistance to pyrethroid insecticides. PLoS One. 2016;11(3):e0150577.

31. Linss JG, Brito LP, Garcia GA, Araki AS, Bruno RV, Lima JB, et al. Distribution and dissemination of the Val1016lle and Phe1534Cys Kdr mutations in Aedes aegypti Brazilian natural populations. Parasit Vectors. 2014;7:25.

32. Saavedra-Rodriguez K, Urdaneta-Marquez L, Rajatileka S, Moulton M, Flores AE, Fernandez-Salas I, et al. A mutation in the voltage-gated sodium channel gene associated with pyrethroid resistance in Latin American Aedes aegypti. Insect Mol Biol. 2007;16(6):785-98.

33. Kasai S, Komagata O, Itokawa K, Shono T, Ng LC, Kobayashi M, Tomita T. Mechanisms of pyrethroid resistance in the dengue mosquito vector, Aedes aegypti: target site insensitivity, penetration, and metabolism. PLoS Negl Trop Dis. 2014:8(6):e2948.

34. Stenhouse SA, Plernsub S, Yanola J, Lumjuan N, Dantrakool A, Choochote W, et al. Detection of the V1016G mutation in the voltage-gated sodium channel gene of Aedes aegypti (Diptera: Culicidae) by allele-specific PCR assay, and its distribution and effect on deltamethrin resistance in Thailand. Parasit Vectors. 2013;6(1):253.

35. Kawada H, Higa Y, Komagata O, Kasai S, Tomita T, Thi Yen N, et al. Widespread distribution of a newly found point mutation in voltage-gated sodium channel in pyrethroid-resistant Aedes aegypti populations in Vietnam. PLoS Negl Trop Dis. 2009;3(10):e527.

36. Du Y, Nomura Y, Satar G, Hu Z, Nauen R, He SY, et al. Molecular evidence for dual pyrethroid-receptor sites on a mosquito sodium channel. Proc Natl Acad Sci U S A. 2013;110(29):11785-90.

37. Kasai S, Ng LC, Lam-Phua SG, Tang CS, Itokawa K, Komagata O, et al. First detection of a putative knockdown resistance gene in major mosquito vector Aedes albopictus Jpn J Infect Dis. 2011;64(3):217-21.

38. Mouchet J, Cordellier R, Germain M, Carnevale P, Barathe J, Sannier C. Résistance aux insecticides d'Aedes aegypti et Culex pipiens fatigans en Afrique Centrale. WHO/NBC/72/381, 1972 12P.

39. Kamgang B, Marcombe S, Chandre F, Nchoutpouen E, Nwane P, Etang J, et al. Insecticide susceptibility of Aedes aegypti and Aedes albopictus in Central Africa. Parasit Vectors. 2011;4:79.

40. Kamgang B, Ngoagouni C, Manirakiza A, Nakoune E, Paupy C, Kazanji M. Temporal Patterns of Abundance of Aedes aegypti and Aedes albopictus (Diptera: Culicidae) and Mitochondrial DNA Analysis of Ae. albopictus in the Central African Republic. PLoS Negl Trop Dis. 2013;7(12):e2590.

41. Jupp PG. Mosquitoes of southern Africa. Culicinae and Toxorhynchitinae. Hartebeesporte: Ekogilde Publishers; 1996.
42. WHO. Guidelines for laboratory and field testing of mosquito larvicides. Document WHO/CDS/WHOPES/GCDPP/13. Geneva: World Health Organization; 2005

43. Abott WS. A simple method of computing the effectiveness of an insecticide. J Econ Entomol. 1925;18:265-7.

44. Giner M, Vassal C, Kouaik Z, Chiroleu F, Vassal JM. Win DL version 2.0. Paris: CIRAD-CA, U.R.B.I/M.A.B.I.S; 1999.

45. Organization $\mathbf{W H}$. Test procedures for insecticide resistance monitoring in malaria vector mosquitoes. Geneva: WHO Document Production Services; 2013.

46. Morlais I, Poncon N, Simard F, Cohuet A, Fontenille D. Intraspecific nucleotide variation in Anopheles gambiae: new insights into the biology of malaria vectors. Am J Trop Med Hyg. 2004;71(6):795-802.

47. Hall TA. BioEdit: a user-friendly biological sequence alignment editor and analysis program for Windows 95/98/NT. Nucl Acids Symp Ser. 1999;41:95-8.

48. Hemingway J, Karunaratne SH. Mosquito carboxylesterases: a review of the molecular biology and biochemistry of a major insecticide resistance mechanism. Med Vet Entomol. 1998;12(1):1-12.

49. Brogdon WG, MCAllister JC, Vulule J. Heme peroxidase activity measured in single mosquitoes identifies individuals expressing an elevated oxidase for insecticide resistance. J Am Mosq Control Assoc. 1997;13(3):233-7.

50. Bradford MM. A rapid and sensitive method for the quantitation of microgram quantities of protein utilizing the principle of protein-dye binding. Anal Biochem. 1976;72:248-54.

51. Paul A, Harrington LC, Zhang L, Scott JG. Insecticide resistance in Culex pipiens from New York. J Am Mosq Control Assoc. 2005;21(3):305-9.

52. Araujo AP, Araujo Diniz DF, Helvecio E, de Barros RA, de Oliveira CM, Ayres CF, et al. The susceptibility of Aedes aegypti populations displaying temephos resistance to Bacillus thuringiensis israelensis: a basis for management. Parasit Vectors. 2013;6(1):297.

53. Carvalho Mdo S, Caldas ED, Degallier N, Vilarinhos Pde T, Souza LC, Yoshizawa MA, et al. Susceptibility of Aedes aegypti larvae to the insecticide temephos in the Federal District, Brazil. Rev Saude Publica. 2004;38(5):623-9.

54. Rocha HD, Paiva MH, Silva NM, de Araujo AP, Camacho Ddos R, Moura AJ, et al. Susceptibility profile of Aedes aegypti from Santiago Island, Cabo Verde, to insecticides. Acta Trop. 2015;152:66-73.

55. Grigoraki L, Lagnel J, Kioulos I, Kampouraki A, Morou E, Labbe P, et al. Transcriptome profiling and genetic study reveal amplified carboxylesterase genes implicated in temephos resistance, in the Asian tiger mosquito Aedes albopictus. PLoS Negl Trop Dis. 2015;9(5):e0003771.

56. Braga IA, Lima JB, Soares Sda S, Valle D. Aedes aegypti resistance to temephos during 2001 in several municipalities in the states of Rio de Janeiro, Sergipe, and Alagoas, Brazil. Mem Inst Oswaldo Cruz. 2004;99(2):199-203.

57. Lima EP, Paiva MH, de Araujo AP, da Silva EV, da Silva UM, de Oliveira LN, et al. Insecticide resistance in Aedes aegypti populations from Ceará. Brazil Parasit Vectors. 2011;4:5.

58. Ayorinde A, Oboh B, Oduola A, Otubanjo O. The insecticide susceptibility status of Aedes aegypti (Diptera: Culicidae) in farm and nonfarm sites of Lagos State, Nigeria. J Insect Sci. 2015;15:75.

59. Vontas J, Kioulos E, Pavlidi N, Morou E. della Torre A, Ranson H. Insecticide resistance in the major dengue vectors Aedes albopictus and Aedes aegypti. Pest Biochem Physiol. 2012;104:126-31.

60. Marcombe S, Farajollahi A, Healy SP, Clark GG, Fonseca DM. Insecticide resistance status of United States populations of Aedes albopictus and mechanisms involved. PLoS One. 2014:9(7):e101992.

61. Jirakanjanakit N, Rongnoparut P, Saengtharatip S, Chareonviriyaphap T, Duchon S, Bellec C, Yoksan S. Insecticide susceptible/resistance status in Aedes (Stegomyia) aegypti and Aedes (Stegomyia) albopictus (Diptera: Culicidae) in Thailand during 2003-2005. J Econ Entomol. 2007;100(2):545-50.

62. Macoris M, Andrighella M, Wanderley D, Ribolla P. Impact of insecticide resistance on the field control of Aedes aegypti in the state of Sao Paulo. Rev Soc Bras Med Trop. 2014;47:573-8.

63. Koffi AA, Alou LP, Adja MA, Kone M, Chandre F, N'Guessan R. Update on resistance status of Anopheles gambiae s.s. to conventional insecticides at a previous WHOPES field site, "Yaokoffikro", 6 years after the political crisis in Cote d'Ivoire. Parasit Vectors. 2012;5:68.

64. Cisse MB, Keita C, Dicko A, Dengela D, Coleman J, Lucas B, et al. Characterizing the insecticide resistance of Anopheles gambiae in Mali. Malar J. 2015;14:327.

65. Ahmad I, Astari S, Tan M. Resistance of Aedes aegypti (Diptera: Culicidae) in 2006 to pyrethroid insecticides in Indonesia and its association with oxidase and esterase levels. Pak J Biol Sci. 2007;10(20):3688-92. 
66. Diallo M, Laganier R, Nangouma A. First record of Ae. albopictus (Skuse 1894), in Central African Republic. Trop Med Int Health. 2010;15(10):1185-9.

67. Araujo HR, Carvalho DO, loshino RS, Costa-da-Silva AL, Capurro ML. Aedes aegypti control strategies in Brazil: Incorporation of new technologies to overcome the persistence of Dengue epidemics. Insects. 2015;6(2):576-94.

68. Paeporn P, Supaphathom K, Srisawat R, Komalamisra N, Deesin V, Ya-umphan P, et al. Biochemical detection of pyrethroid resistance mechanism in Aedes aegypti in Ratchaburi province. Thailand Trop Biomed. 2004;21(2):145-51.

69. Rodriguez MM, Bisset JA, Fernandez D. Levels of insecticide resistance and resistance mechanisms in Aedes aegypti from some Latin American countries. J Am Mosq Control Assoc. 2007;23(4):420-9.

Submit your next manuscript to BioMed Central and we will help you at every step:

- We accept pre-submission inquiries

- Our selector tool helps you to find the most relevant journal

- We provide round the clock customer support

- Convenient online submission

- Thorough peer review

- Inclusion in PubMed and all major indexing services

- Maximum visibility for your research

Submit your manuscript at www.biomedcentral.com/submit
C) Biomed Central 